\title{
Lymphoid organ virus of Penaeus monodon from Australia
}

\author{
K. M. Spann ${ }^{1, *}$, J. E. Vickers ${ }^{2}$, R. J. G. Lester ${ }^{1}$ \\ ${ }^{1}$ Department of Parasitology, ${ }^{2}$ Department of Microbiology, The University of Queensland, Brisbane, \\ Queensland 4072, Australia
}

\begin{abstract}
Subadult Penaeus monodon shrimp were sampled from 4 farms in Queensland, Australia. Histological observations on lymphoid organs showed the formation of abnormal cell foci, which resembled tubules lacking a central hemolymph vessel. These formations contained hypertrophied nuclei with marginated chromatin, vacuolated cells and inclusion bodies which stained positive with Feulgen's reaction. Male and female $P$. monodon broodstock were sampled from 1 farm and showed the same abnormal histological features within the lymphoid organ as the subadults. Electron microscopy revealed tightly enveloped, cylindrical particles, $163-200 \mathrm{~nm} \times 36-63 \mathrm{~nm}$, packed into paracrystalline arrays within the cytoplasm and infrequently within the nucleus. Arrays of virions were also observed within the cytoplasm of broodstock gill cells. Cross-sections of the particles revealed electron dense nucleic acid cores and envelopes. Nucleocapsids, $83-590 \mathrm{~nm} \times 13-15 \mathrm{~nm}$, were seen free and in vesicles within the cytoplasm. A negatively stained preparation of partially purified lymphoid organ revealed a nucleocapsid with one conical end. Lymphoid organ virus (LOV) resembles yellow-head virus (YHV) from Thailand in its morphology and cytopathology and rhabdovirus of penaeid shrimp (RPS) from the Americas in its cytopathology.
\end{abstract}

KEY WORDS: Lymphoid organ virus (LOV) - Yellow-head virus (YHV) - Bacilliform · Asymptomatic

\section{INTRODUCTION}

At least 6 viruses have been described from the lymphoid organ of penaeid shrimp. Infectious hypodermal and hematopoietic necrosis virus (IHHNV) was first described by Lightner et al. (1983) from Penaeus stylirostris, $P$. vannamei and $P$. monodon and was recently reported from a hybrid shrimp raised in a laboratory in Queensland, Australia (Owens et al. 1992). Owens et al. (1991) described lymphoidal parvoviruslike virus (LPV), a virus which appears to be present exclusively in the lymphoid organ of $P$. monodon subadults. Lymphoid organ vacuolization virus (LOVV), a togavirus, has been partially characterised from abnormal lymphoid organs of $P$. vannamei (Bonami et al. 1992). Flegel et al. (1992) reported reovirus-like particles from the lymphoid organs of broodstock prawns in Thailand

\footnotetext{
•E-mail: s304011@student.uq.edu.au
}

The causative agent of yellow head disease in Penaeus monodon of Thailand has been identified as a bacilliform virus (YHV) which infects the lymphoid organ, gills and other organs (Boonyaratpalin et al. 1993). The genome is RNA and therefore YHV may be a rhabdovirus or a coronavirus (Wongteerasupaya et al. 1995). This virus is one of the most virulent disease agents so far reported for $P$. monodon, causing massive mortalities among subadult prawns within $3 \mathrm{~d}$ of first diagnosis (Chantanachookin et al. 1993).

Rhabdovirus of penaeid shrimp (RPS) was described by Lu et al. (1991) for Penaeus stylirostris and $P$. vannamei infected with IHHNV. This virus appears to occur exclusively in the lymphoid organ. Prawns infected with RPS alone show no signs of clinical disease.

The virus described in this paper, which we have called lymphoid organ virus (LOV), shares histopathological and cytopathological features with YHV and RPS. 


\section{MATERIALS AND METHODS}

Source and preparation of specimens. Forty subadult Penaeus monodon prawns, weighing between 10 and $30 \mathrm{~g}$, were collected from 4 farms in Queensland, Australia, 10 from each farm. Two male and eight female broodstock prawns, weighing between 96 and $130 \mathrm{~g}$, were sampled from one of the farms. The cephalothorax of the prawns was separated from the abdomen, and split longitudinally. One longitudinal section was fixed in Davidson's fixative and processed for histology. Sections were stained using Feulgen's DNA reaction (Humason 1968).

Electron microscopy. The remaining portions of the lymphoid organ, gills, heart, nerve cord, hepatopancreas and hematopoietic tissue were diced and fixed in $2.5 \%$ gluteraldehyde $/ 2 \%$ paraformaldehyde in cacodylate buffer and postfixed in $1 \%$ osmium tetroxide. The tissue was dehydrated through a graded series of alcohol and mounted in Spurr's resin (Spurr 1969). Sections were cut at $50 \mathrm{~nm}$, stained with uranyl acetate $/ 70 \%$ methanol and Reynold's lead citrate and viewed at $80 \mathrm{kV}$ under Phillips $400 \mathrm{~T}$ and Hitachi H-800 transmission electron microscopes (TEM).

Virus purification. Lymphoid organs (LOs) $(1.21 \mathrm{~g})$ were dissected from 50 subadult prawns collected from one of the farms where infected prawns had been found. The LOs were immediately placed onto dry ice and stored at $-70^{\circ} \mathrm{C}$ for $1 \mathrm{wk}$. Lymphoid organs were homogenized on ice in $40 \mathrm{ml} 0.2 \mathrm{M} \mathrm{NaCl} / 0.02 \mathrm{M}$ Tris$\mathrm{HCl}, \mathrm{pH} 7.4$ (NT), using a $7 \mathrm{ml}$ Corning sintered glass homogenizer. The homogenate was clarified at $2500 \times g$ for $5 \mathrm{~min}$ at $4^{\circ} \mathrm{C}$. The supernatant was then centrifuged in the same centrifuge at $48400 \times g$ for $45 \mathrm{~min}$ at $4^{\circ} \mathrm{C}$ to pellet the virions. The pellet was resuspended in $1 \mathrm{ml} \mathrm{NT}$ and centrifuged on a sucrose cushion, consisting of $1 \mathrm{ml} 60 \%(\mathrm{w} / \mathrm{w}$ ) sucrose in NT beneath $10 \mathrm{ml} 20 \%$ (w/w) sucrose in NT at $103000 \times \mathrm{g}$ for $2 \mathrm{~h}$ at $4^{\circ} \mathrm{C}$ in a Beckman L8-M ultracentrifuge. The bands that formed at the interface were collected, diluted 5-fold and then pelleted at $208500 \times g$ for $1 \mathrm{~h}$ at $4^{\circ} \mathrm{C}$. Pellets were resuspended in $500 \mu \mathrm{l} \mathrm{NT}$, and $5 \mu \mathrm{l}$ pipetted onto a Formvar coated $\mathrm{Cu}-400$ mesh grid, which was stained with $2 \%$ sodium phosphotungstic acid ( $\mathrm{pH}$ 6.8) and examined under a Hitachi $\mathrm{H}-800$ electron microscope.

\section{RESULTS}

The sampled prawns, subadults and broodstock, showed no signs of clinical disease and the populations were not suffering mortalities at the time of sampling

\section{Histology}

Normal lymphoid organs are composed of tubules with a central hemolymph vessel surrounded by a stromal matrix of cells (Bell \& Lightner 1988). The lymphoid organs of all prawns from the 4 farms contained abnormal foci of cells, which resembled tubules lacking a central hemolymph vessel (Fig. 1). These areas counter-stained light green with Feulgen's reaction whereas normal tubules stained a darker green. The cells within these areas contained hypertrophied nuclei (diameter approximately 1.3 times that of normal nuclei; Fig. 2) with marginated chromatin and large vacuoles. Evident in the Feulgen's preparations were globose, cytoplasmic inclusion bodies which stained positive (red), suggesting the presence of DNA (Fig. 2). It was difficult to distinguish these inclusions from pyknotic nuclei, except in cells where the inclusion was directly adjacent to the nucleus (Fig. 2). These bodies occurred within the abnormal cell foci. All other organs showed normal histology. Pyknotic nuclei were occasionally seen in the gills, the wall of the oesophagus and the hepatopancreas of the subadults.

\section{Electron microscopy}

Cylindrical enveloped virus particles, 163 to $200 \mathrm{~nm}$ long and 36 to $63 \mathrm{~nm}$ wide, were found in the cytoplasm of some lymphoid organ cells, packed into paracrystalline

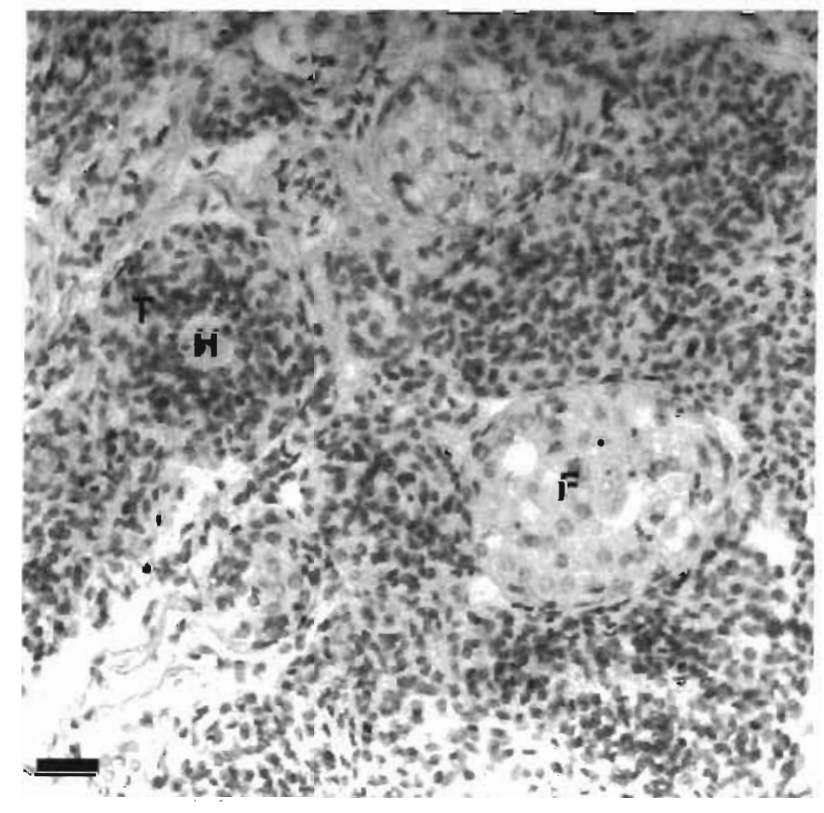

Fig. 1 Penaeus monodon. Lymphoid organ of a subadult infected with LOV. Infected lymphoid organs contain foci of cells $(F)$ which resemble normal tubules $(T)$ lacking a central hemolymph vessel $(\mathrm{H})$. Scale bar $=10 \mu \mathrm{m}$. Feulgen's reaction 


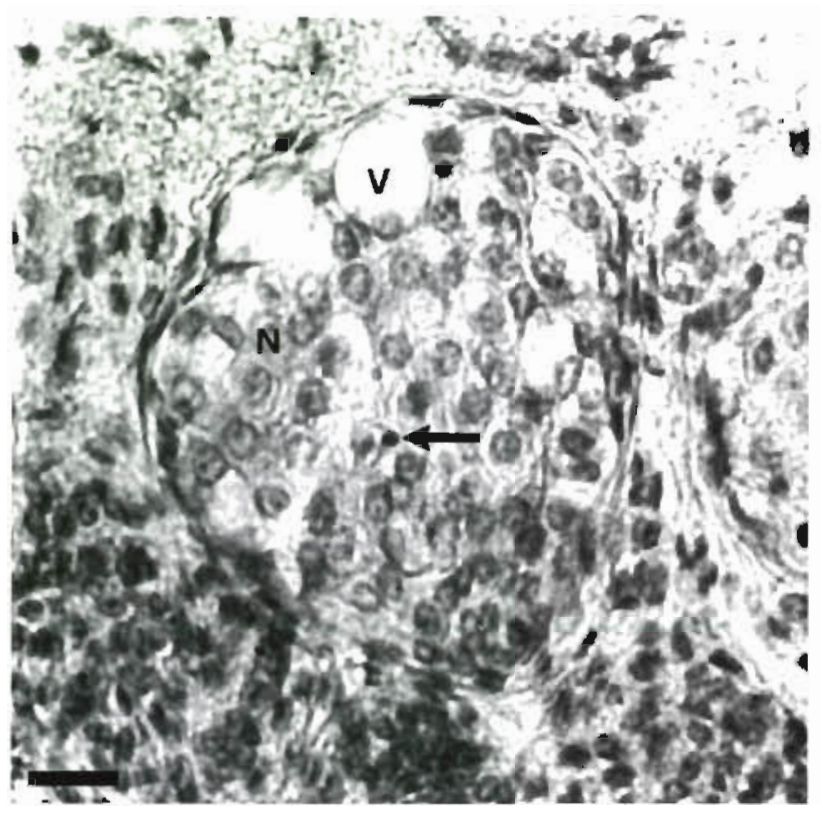

Fig. 2. Penaeus monodon. Higher magnification of a focus of cells with hypertrophied nuclei $(N)$, vacuoles (V) and cytoplasmic inclusion bodies (arrow). Scale bar $=4 \mu \mathrm{m}$. Feulgen's reaction

arrays (Fig. 3). These arrays were often associated with vesicles of viral material (Fig. 4). Virus particles were not observed in other organs of the subadult prawns. The nucleocapsids within the envelopes appeared striated (Fig. 5). The number of virions within an array varied from 3 to over 60 virions. Groups of virions were observed at the plasma membrane (Fig. 6). Virions had an electron dense nucleic acid core (12 to $22 \mathrm{~nm}$ in diameter) surrounded by a translucent layer ( 3 to $11 \mathrm{~nm}$ thick) and electron dense envelope (12 to $23 \mathrm{~nm}$ thick) (Figs. 4, 5 \& 6). Enveloped virions were seen in the lymphoid organ and gills (Fig. 7) of both male and female broodstock. Long enveloped filaments which appeared to be undergoing fragmentation were observed (Fig. 7 inset).

Unenveloped filaments, 83 to $290 \mathrm{~nm}$ long and 13 to $15 \mathrm{~nm}$ wide, occurred free in the cytoplasm (Fig. 8). The termini of some nucleocapsids appeared conical. Some of the nucleocapsid cores appeared hollow, suggesting that packing of nucleic acid into the capsids was not complete. Filaments were observed in association with endoplasmic reticulum (Fig. 9). Enveloped virions were occasionally seen along the inner surface of nuclear membranes (Fig. 10 and inset A) while unenveloped nucleocapsids occurred outside the membranes (Fig. 10 and inset B).

\section{Virus purification}

Material collected at the sucrose cushion interface contained cell debris and a cylindrical, tightly enveloped particle (161 $\mathrm{nm} \times 45 \mathrm{~nm}$ ), with surface projections up to $8 \mathrm{~nm}$ in length (Fig. 11). A cylindrical structure (145 $\mathrm{nm} \times 25 \mathrm{~nm})$, discernible within the envelope, possessed surface striations similar to those of unenveloped nucleocapsids (Fig. 8) and appeared to have one conical end.

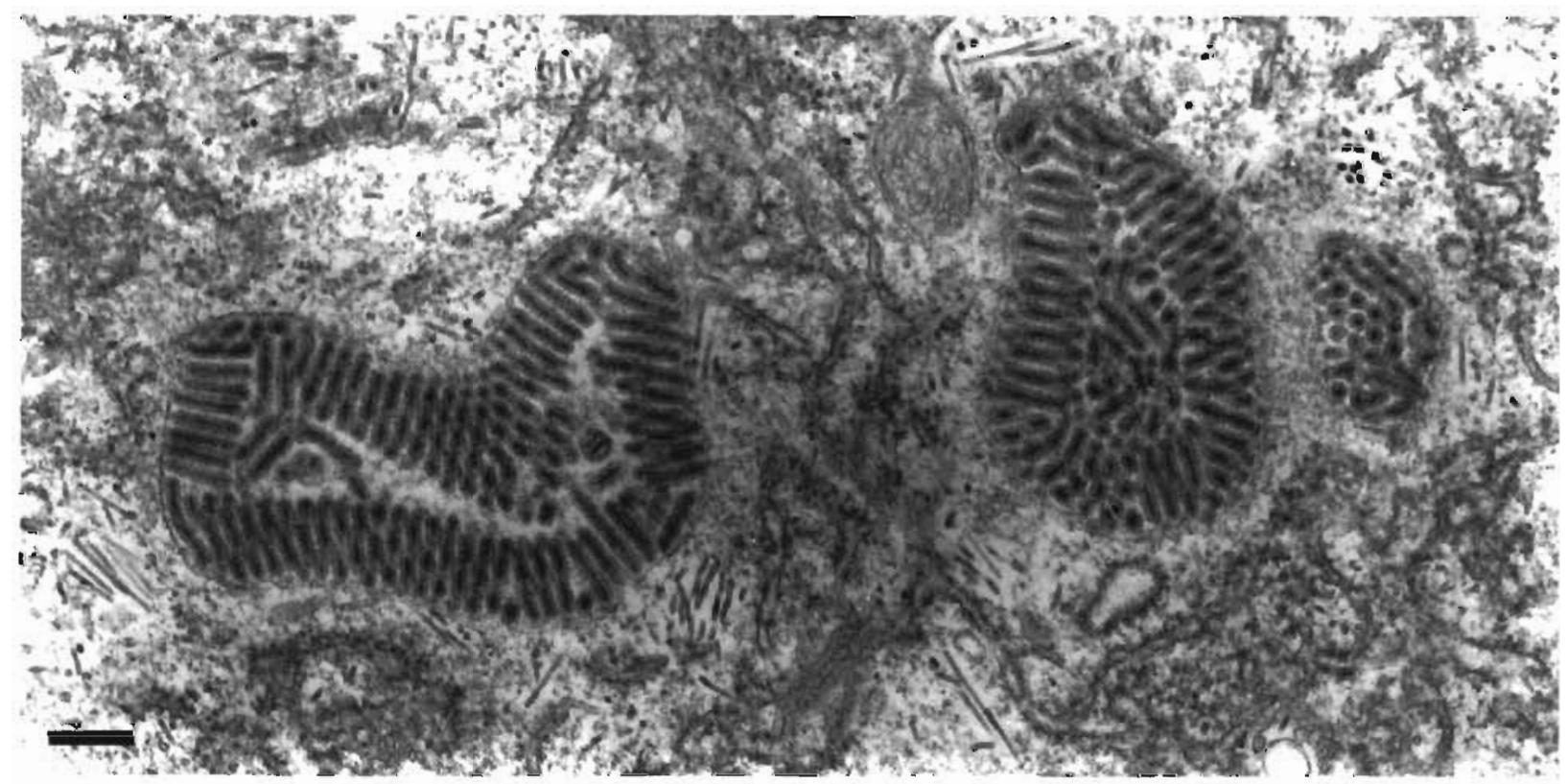

Fig. 3. An LOV infected Penaeus monodon cell showing paracrystalline arrays of enveloped virions within the cytoplasm. Scale bar $=200 \mathrm{~nm}$ 


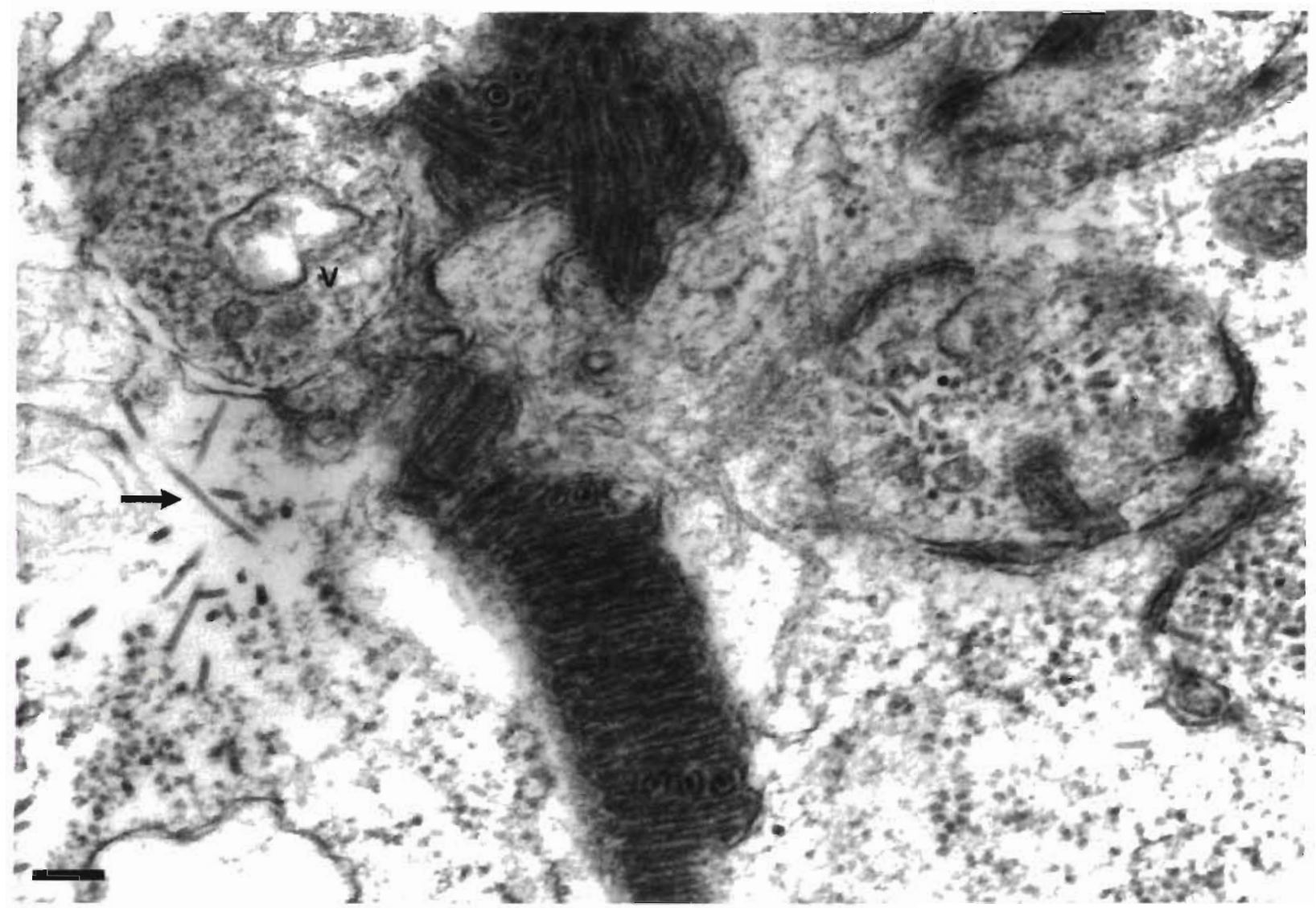

Fig. 4. Enveloped virions of LOV (infecting Penaeus monodon) in paracrystalline arrays which are associated with vesicles (V) of viral material and are surrounded by unenveloped virions free in the cytoplasm (arrow). Scale bar $=100 \mathrm{~nm}$

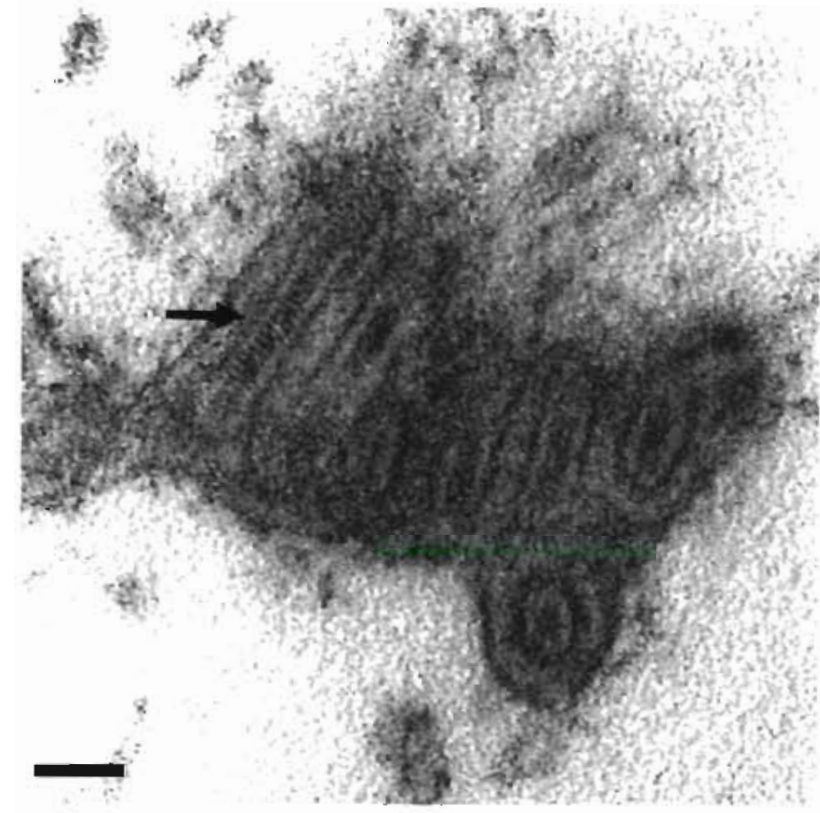

Fig. 5. A small array of LOV virions contained within a vesicle in the cytoplasm of an infected lymphoid organ cell of Penaeus monodon. The striations of the nucleocapsid are evident (arrow). Scale bar $=50 \mathrm{~nm}$

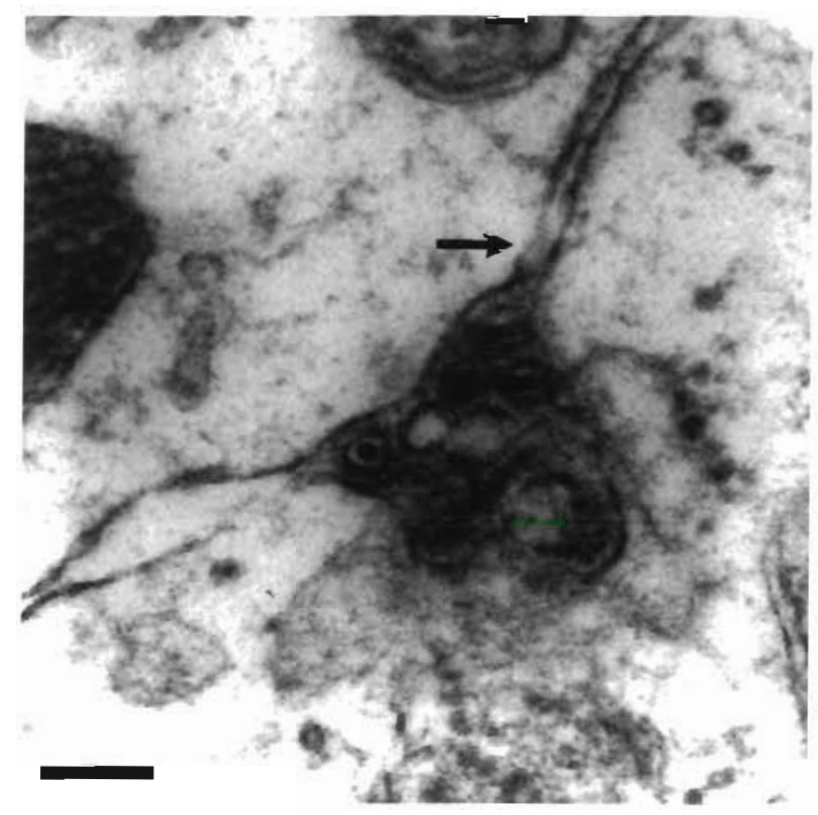

Fig. 6. An array of LOV virions (infecting Penzeus monodon) which appears to be budding through the plasma membrane (arrow) into an adjacent cell. Scale bar $=100 \mathrm{~nm}$ 


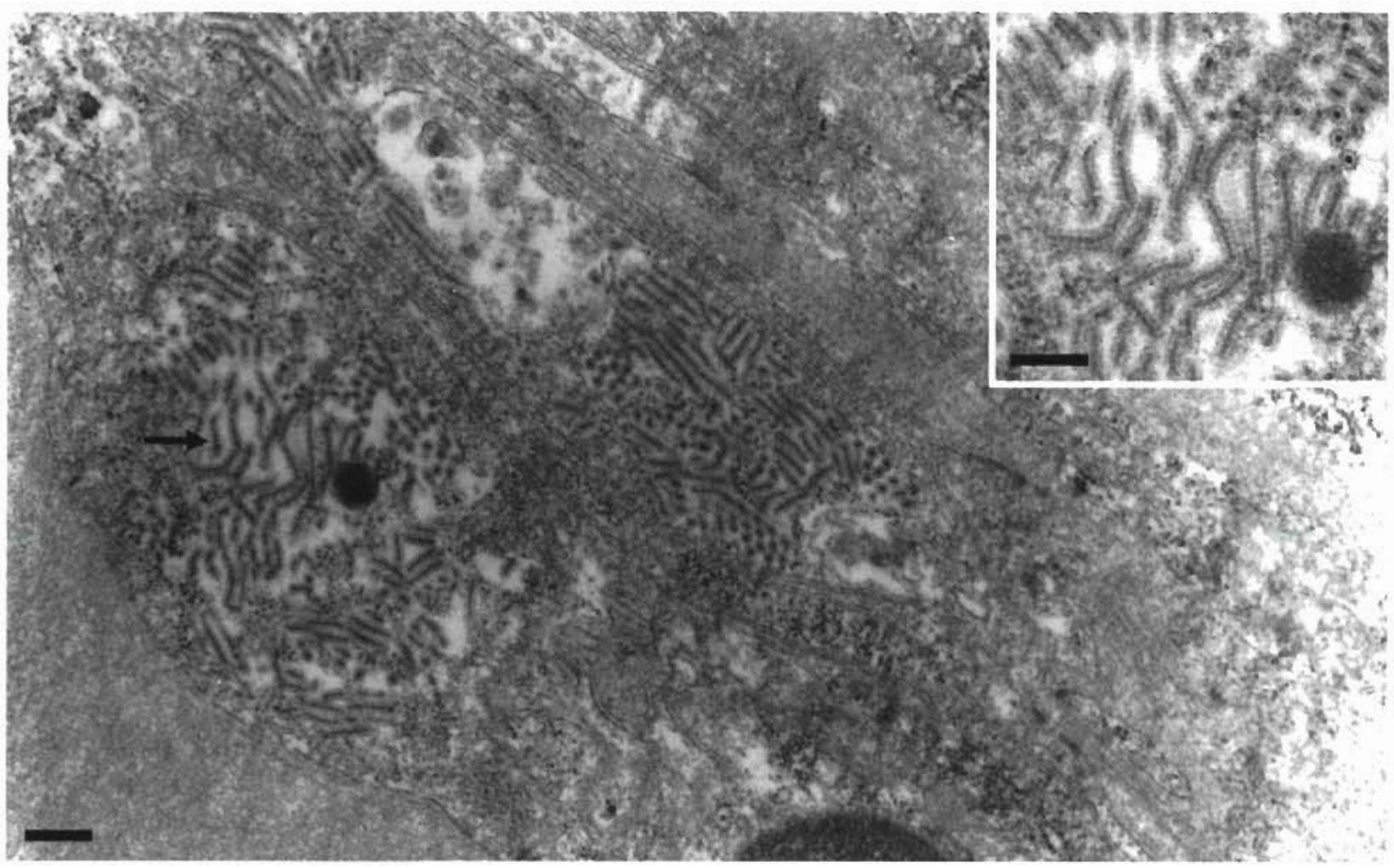

Fig. 7. Arrays of enveloped LOV virions within the gill cells of a female Penaeus monodon broodstock prawn. Arrow shows the area of inset. Scale bar $=300 \mathrm{~nm}$. Inset: Enveloped filaments undergoing fragmentation to form smaller virions. Scale bar $=200 \mathrm{~nm}$

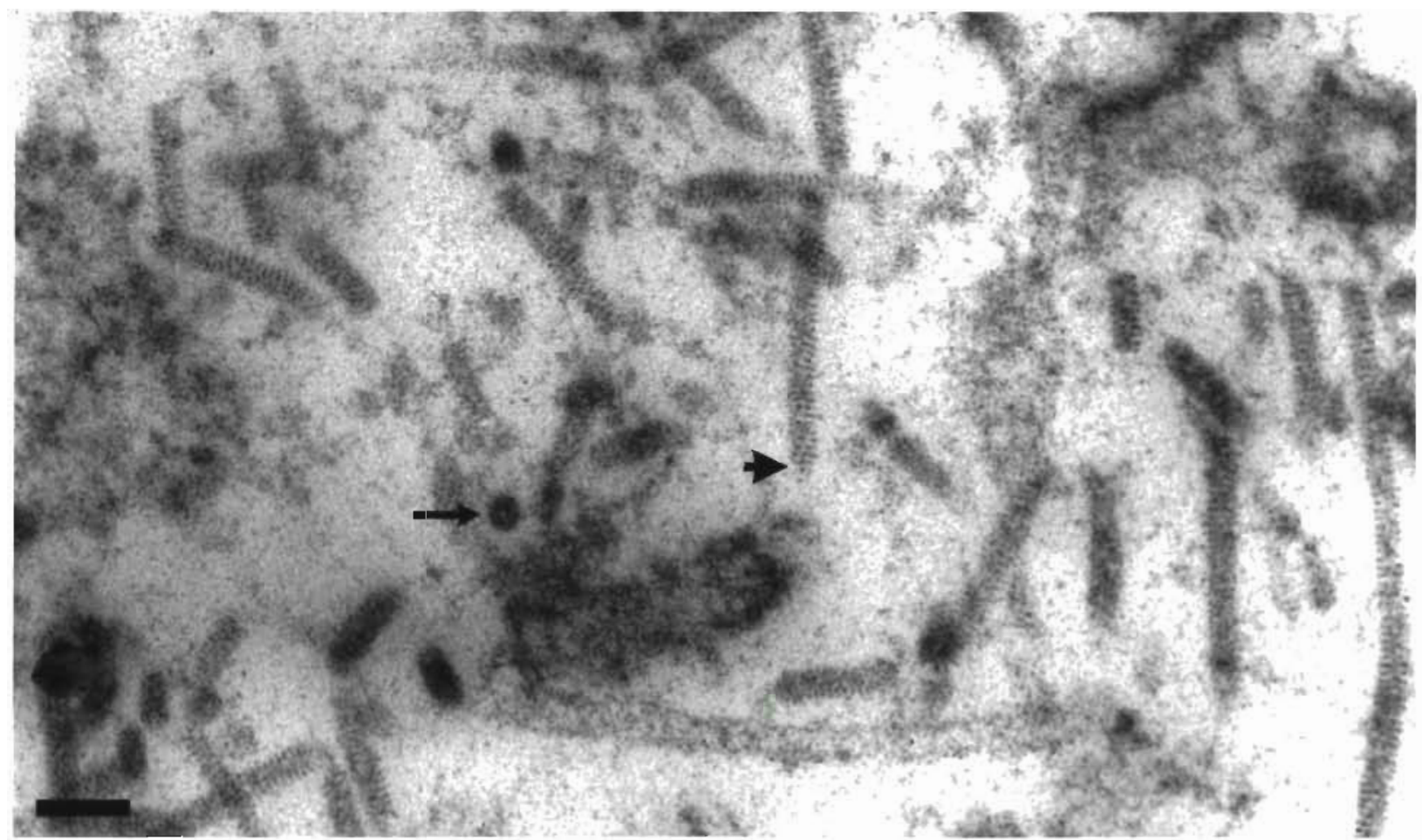

Fig. 8. Unenveloped nucleocapsids of LOV in the cytoplasm of an infected Penaeus monodon cell. The termini of some nucleocapsids appear conical (arrowhead). Some nucleocapsids in cross-section appear to be hollow (arrow), indicating that nucleic acid formation is not complete. Scale bar $=100 \mathrm{~nm}$ 


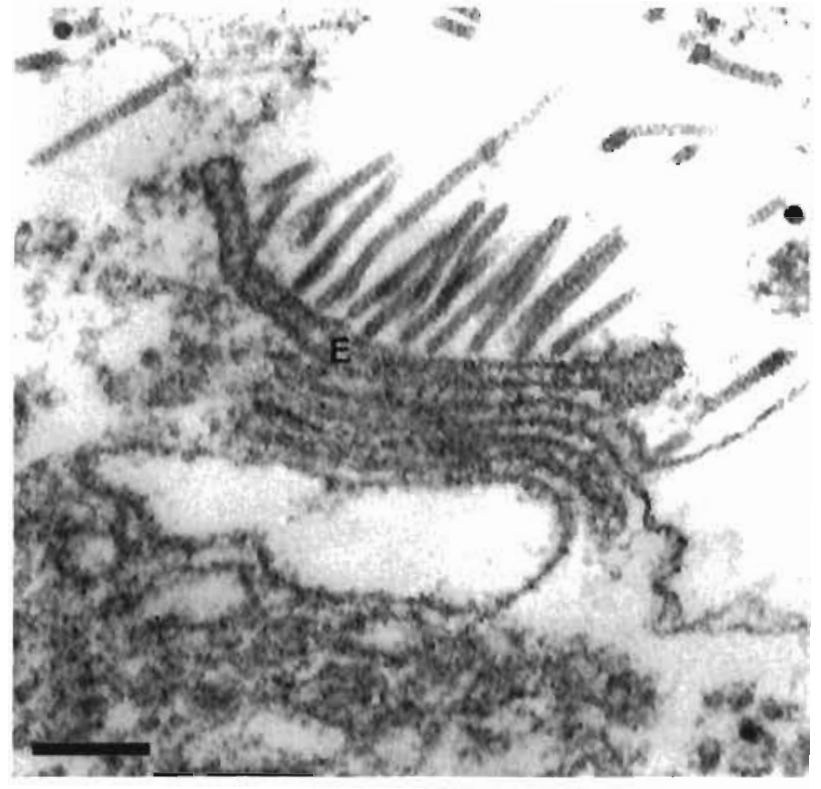

Fig. 9. Unenveloped filaments associated with endoplasmic reticulum (E) within an infected lymphoid organ cell of Penaeus monodon. Scale bar $=100 \mathrm{~nm}$

\section{DISCUSSION}

The results indicate the presence of a previously undescribed bacilliform virus which occurs primarily in the lymphoid organs of Penaeus monodon prawns farmed in Queensland. The histopathological features associated with this virus (cell foci resembling tubules lacking a central hemolymph vessel, hypertrophied nuclei with marginated chromatin, large cytoplasmic vacuoles and Feulgen-positive, cytoplasmic inclusion bodies) are also associated with other lymphoid organ viruses, LOVV (Bonami et al. 1992), LPV (Owens et al. 1991), a reovirus and YHV (Flegel et al. 1992) and RPS (Lu et al. 1991).

The presence of cytoplasmic inclusion bodies, which stain positive with Feulgen's reaction, suggests the presence of a DNA-containing virus. However, replication and virion accumulation appear to occur in the cytoplasm, which is typical of RNA viruses and few DNA viruses (Franki et al. 1991). The genome of this virus has not yet been characterised.

The virus described here is reminiscent of rhabdoviruses in size and morphology. The virion supports short surface projections and may be bullet shaped as there is a suggestion that the nucleocapsid has a

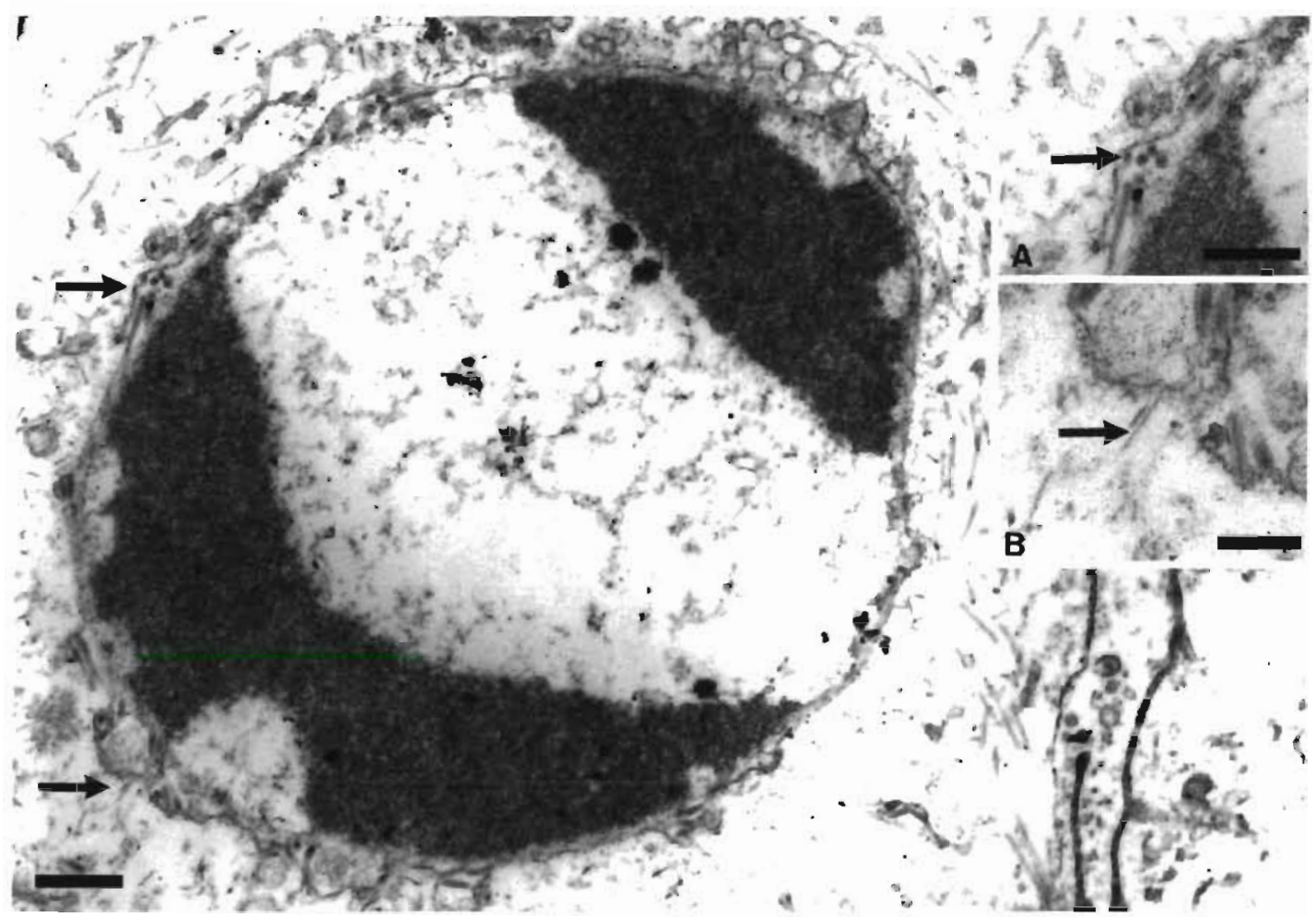

Fig. 10. Nucleus of an infected lymphoid organ cell of Penaeus monodon. Scale bar $=600 \mathrm{~nm}$. Arrows show the areas of insets. Inset A: Enveloped virions (arrow) within the nuclear membrane. Scale bar $=400 \mathrm{~nm}$. Inset $B$ : Unenveloped virions (arrow) outside the nuclear membrane. Scale bar $=200 \mathrm{~nm}$ 


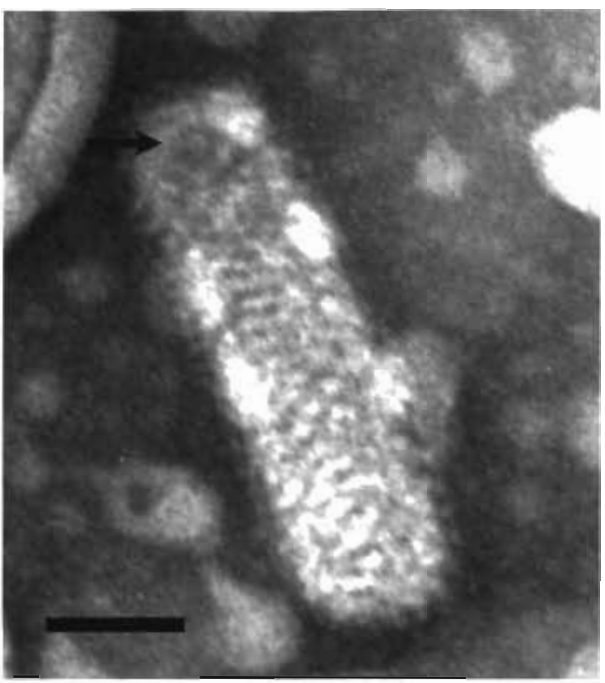

Fig. 11. Cylindrical, enveloped particle (purified from Penaeus monodon lymphoid organs) with apparent projections, striated nucleocapsid and one conical end (arrow). Scale bar $=50 \mathrm{~nm}$

conical end. The nucleocapsid is of helical symmetry (Franki et al. 1991). Rhabdovirus particles may be as long as those seen in Fig. 8. The accumulation of the virus within vesicles in the cytoplasm is typical of slowly maturing rhabdoviruses (Brun 1991). Replication appears to occur in the cytoplasm, however there is evidence of some nuclear involvement which is atypical of rhabdoviruses.

LOV is similar in its ultrastructural and cytopathological features to YHV of Thailand and in its cytopathological features to RPS of the Americas. The virus described here and YHV both infect Penaeus monodon subadults and involve the lymphoid organ and gills. Paracrystalline arrays of virions within the cytoplasm are characteristic of both viruses, and the virions are similar in size $[173 \pm 13 \mathrm{~nm} \times 44 \pm 6 \mathrm{~nm}$ for enveloped YHV (Chantanachookin et al. 1993) and 163-200 $\mathrm{nm} \times 36-62 \mathrm{~nm}$ for LOV). The abundant filamentous material, possibly nucleic acid cores, is characteristic of both viruses.

The partially purified enveloped particle is similar in appearance to purified YHV particles (Wongteerasupaya et al. 1995). Viral envelopes appear to be acquired by passage through the rough endoplasmic reticulum which then forms a vesicle around the virions. This process of envelope acquisition has been suggested for YHV by Chantanachookin et al. (1993).

A notable difference between this virus and YHV is the lack of any obvious effect on the health of the shrimp, as YHV is one of the most highly pathogenic prawn viruses with mortalities reaching 100\% (Chantanachookin et al. 1993). However, Flegel et al. (1992) observed cytoplasmic, enveloped, rod-shaped virions identical to YHV in the lymphoid organs of outwardly healthy broodstock and Chantanachookin et al. (1993) have suggested that this infection is the latent asymptomatic form of YHV. Particles apparently identical to LOV were observed in Queensland broodstock. It is possible that YHV may have arisen from an asymptomatic virus similar to LOV.

LOV resembles RPS in that prawns infected with RPS show no overt signs of disease (Lu \& Loh 1992). RPS appears to exclusively infect the lymphoid organ and has the previously mentioned characteristics typical of rhabdoviruses. The primary site of budding of rhabdoviruses is the cellular membrane, however virions of LOV and RPS also bud from cytoplasmic vesicular sites.

Acknowledgements. Mr R. Webb of the Centre for Microscopy and Microanalysis, The University of Queensland, is thanked for his interpretation of photomicrographs. The research was supported by the Australian Research Council, AA8931446 and A0921051.

\section{LITERATURE CITED}

Bell TA, Lightner DV (1988) A handbook of normal penaeid shrimp histology. The World Aquaculture Society, Baton Rouge

Bonami JR, Lightner DV, Redman RM, Poulos BT (1992) Partial characterization of a togavirus (LOVV) associated with histopathological changes of the lymphoid organ of penaeid shrimps. Dis aquat Org 14:145-152

Boonyaratpalin S, Supamattaya K, Kasornchandra J, Direkbusaracom S, Aekpanithanpong U, Chantanachooklin C (1993) Non-occluded baculo-like virus the causative agent of yellowhead disease in the black tiger shrimp. Gyobyo Kenkyu 28:103-109

Brun G (1991) Rhabdoviridae. In: Adams JR, Bonami JR (eds) Atlas of invertebrate viruses. CRC Press, Boca Raton, p $443-460$

Chantanachookin C, Boonyaratpalin S, Kasornchandra J, Direkbusarakom, S, Ekpanithanpong U, Supamataya K, Sriurairatana S, Flegel TW (1993) Histology and ultrastructure reveal a new granulosis-like virus in Penaeus monodon affected by yellow-head disease. Dis aquat Org 17:145-157

Flegel TW, Fegan DF, Kongsom S, Vuthikornudomkit S, Sriurairatana $S$, Boonyaratpalin $S$, Chantanachookin C, Vickers JE, Macdonald OD (1992) Occurrence, diagnosis and treatment of shrimp diseases in Thailand. In: Fulks W, Main KL (eds) Diseases of cultured penaeid shrimp in Asia and the United States. The Oceanic Institute, Honolulu, p 57-112

Francki RIB, Farquet CM, Knudson DL, Brown F (eds) (1991) Classification and nomenclature of viruses. Fifth report of the International Committee on Taxonomy of Viruses. Springer-Verlag, New York, p 250-262

Humason GL (1968) Animal tissue techniques. WH Freeman and $\mathrm{Co}$, San Francisco

Lightner DV, Redman RH, Bell TA (1983) Infectious hypodermal and hematopoietic necrosis virus, a newly recognised virus disease of penaeid shrimp. J Invertebr Pathol $42: 62-70$ 
Lu Y, Loh PC (1992) Some biological properties of a rhabdovirus isolated from penaeid shrimps. Arch Virol 127 $339-343$

Lu Y, Nadala ECB Jr, Brock JA, Loh PC (1991) A new virus isolate from infectious hypodermal and hematopoietic necrosis virus (IHHNV)-infected penaeid shrmmps. $J$ virol Methods 31:189-1.96

Owens L, Andersen IG, Kenway M. Trott L, Benzie JAH (1992) Infectious hyperdermal and haematopoietic necrosis virus (IHHNV) in a hybrid penaeid prawn from tropical Australia. Dis aquat Org 14:219-228

Responsible Subject Editor: J. E. Stewart, Dartmouth, Nova Scotia, Canada
Owens L, De Beer S. Smith J (1991) Lymphoid parvo-like particles in Australian penaeid prawns. Dis aquat Org 11: $129-134$

Spurr AR (1969) A low viscosity epoxy resin embedding medium for electron microscopy. J Ultrastruct Res 26 : $31-43$

Wongteerasupaya C, Sriurairatana S, Vickers JE, Akrajamorn A, Boonsaeng V, Panyim S, Tassanakajon A, Withyachunmarnkul B, Flegel TW (1995) Yellow-head virus of Penaeus monodon is an RNA virus. Dis aquat Org 22: $45-50$

Manuscript first received: December 29, 1994 Revised version accepted: May 11, 1995 